УДК 796.412

DOI https://doi.org/10.26661/2663-5925-2021-3-06

\title{
ШЛЯХИ ВДОСКОНАЛЕННЯ ХОРЕОГРАФІЧНОЇ ПІДГОТОВЛЕНОСТІ СПОРТСМЕНОК У СПОРТИВНІЙ АЕРОБІЦІ
}

\author{
Шеховцова К. В. \\ аспірантка кафедри теорії та методики фізичної культури і спорту \\ Запорізький національний університет \\ вул. Жуковського, 66, Запоріжжя, Украӥна, \\ викладач кафедри фізичної культури, олімпійських та неолімпійських видів спорту \\ Національний університет «Запорізька політехніка» \\ вул. Гоголя, 70-В, Запоріжжя, Украӥна, \\ orcid.org/0000-0002-1604-1566 \\ k.shekhovtsova.k@gmail.com
}

Тищенко В. О.

доктор наук з фізичного виховання і спорту, професор, професор кафедри теорії та методики фізичної культури і спорту,

Запорізький національний університет

вул. Жуковського, 66, м. Запоріжжя, Украӥна

orcid.org/0000-0002-9540-9612

valeri-znu@ukr.net

Ключові слова: танциі, художньо-гімнастичні види спорту, технічна майстерність, фізичні якості, танцювальні рухи.
Сьогодні виникають деякі складнощі під час тренування в спортивній аеробіці, особливо щодо хореографічного складника. Враховуючи специфічні тенденції розвитку цього виду спорту, бажано сприяти покращенню виразності рухів та композиційної підготовки. У роботі розглядаються напрями хореографічної підготовки з точки зору вимог до підготовки відповідних вправ. Мета дослідження - здійснити аналіз фахової літератури та обгрунтувати засоби і методи вдосконалення хореографічної підготовленості спортсменок у спортивній аеробіці. Об'єкт дослідження - навчально-тренувальний процес спортсменок у спортивній аеробіці. Предмет дослідження - засоби і методи вдосконалення хореографічної підготовленості спортсменок у спортивній аеробіці. Під час роботи використано методи теоретичного рівня дослідження: абстрагування, аналогію, аналіз, узагальнення, що спрямовані на виявлення проблем і суперечностей, пов’язаних із хореографічною підготовленістю спортсменок у спортивній аеробіці. Спираючись на положення кодексу підрахунку балів FIG, автори дослідження мали на меті проаналізувати відповідну літературу останніх років та визначити сучасні тенденції в підготовці хореографії 3 відповідним впливом на художню підготовку. Навіть якщо навчальні елементи підсилюють один одного, їх взаємозв'язок уже давно обгрунтовано, хореографічна підготовка набуває все більш чіткої самобутності, власної структурованої концепції, різних складних джерел походження. Здійснено спробу ранжування даних, що стосуються складників хореографічного руху, як вони аналізуються в літературі останніх років, щодо до особливих вимог до спортивної аеробіки. Подано структуру хореографічної композиції. Удосконалення хореографічної підготовленості спортсменок у спортивній аеробіці може бути довготривалим, адже воно пов'язано з освітніми знаннями та навичками спортсменок, які впливатимуть на якість виконання різних елементів. Тому необхідно застосовувати комплексний підхід 
для одночасного покращення танцювальних та фізичних якостей, синтезувати різні засоби та методи, дбати про всебічний розвиток спортсменок.

\title{
WAYS TO IMPROVE CHOREOGRAPHICAL PREPAREDNESS OF ATHLETES IN SPORTS AEROBICS
}

\author{
Shekhovtsova K. V. \\ Postgraduate Student at the Department of Theory and Methods of Physical Culture and Sports \\ Zaporizhzhia National University \\ Zhukovskoho str., 66, Zaporizhzhia, Ukraine \\ Lecturer at the Department of Physical Culture, Olympic and non-Olympic Sports "Zaporizhzhia \\ Polytechnic" National University \\ Gogolya str., 64, Zaporizhzhia, Ukraine \\ orcid.org/0000-0002-1604-1566 \\ k.shekhovtsova.k@gmail.com
}

Tyshchenko V. O.

Doctor of Sciences in Physical Education and Sports, Professor, Professor at the Department of Theory and Methods of Physical Culture and Sports

Zaporizhzhia National University

Zhukovskoho str., 66, Zaporizhzhia, Ukraine

orcid.org/0000-0002-9540-9612

valeri-znu@ukr.net

Key words: dance, rhythmic gymnastics sports, technical skills, physical qualities, dance movements.
Today there are some difficulties during training in sports aerobics, especially in the choreographic component. Taking into account the specific trends in the development of this sport, it is desirable to improve the expressiveness of movements and compositional training. The paper considers the areas of choreographic training in terms of requirements for the preparation of relevant exercises. The purpose of the research is to analyze the professional literature and substantiate the means and methods of improving the choreographic training of athletes in sports aerobics. The object of the research is the educational process of sportswomen in sports aerobics. The subject of the research is means and methods of improving the choreographic training of athletes in sports aerobics. During the research the methods of theoretical level of research were used: abstraction, analogy, analysis, generalizations, which are aimed at identifying the problems and the contradictions related to the choreographic training of athletes in sports aerobics. Based on the provisions of the FIG scoring code, this research aims to analyze the relevant literature of the recent years and identify the current trends in the preparation of choreography with an appropriate impact on artistic training. Even if the learning elements reinforce each other, their relationship has long been justified, choreographic training is gaining a clearer identity, its own structured concept, various complex sources of origin. An attempt has been made to rank the data relating to the components of the choreographic movement, as they are analyzed in the literature of the recent years, in relation to the special requirements of sports aerobics. The structure of the choreographic composition is given. Improving the choreographic training of athletes in sports aerobics can last for a long-time, as it is associated with the educational knowledge and the skills of athletes, which will affect the quality of performance of various elements. Therefore, it is necessary to apply a comprehensive approach to the simultaneous improvement of dance 
and physical qualities, to synthesize different tools and methods, to take care of the comprehensive development of athletes.

Вступ. 3 кожним роком у спортивній аеробіці набуває великого значення хореографічна підготовка у зв'язку зі зростаючою динамікою виконання змагальних програм, що вимагає підвищення рівня фізичних якостей спортсменів, удосконалення їхньої технічної майстерності. Вона належить до одного 3 провідних компонентів, оскільки впливає на процес підготовки спортсменок різних класів та видів спорту, формує загальну та рухову культуру, розвиває творче мислення, що виражається у спеціально-фізичній, спеціально-технічній, естетичній спрямованості. Виступ спортсмена включає в себе досконале тіло, фізичну i технічну віртуозність, чудовий контроль моторики, високу чутливість.

Тонкий обмін між тілом як біомеханічною системою та всім сприйняттям, почуттями та думками, які супроводжують людські рухи, 3 освітньої, артистичної чи спортивної точки зору вибудовують певний взаємозв'язок, який є базовою матрицею в художньо-гімнастичних видах спорту, де процес створення та вираження цих рухів $є$ проблемою. Всі ці аспекти потребують детального розгляду та аналізу, тому для сучасної науки означена тема $є$ досить актуальною.

Мета дослідження - здійснити аналіз фахової літератури та обгрунтувати засоби і методи вдосконалення хореографічної підготовленості спортсменок у спортивній аеробіці.

Методи дослідження. Під час роботи використано методи теоретичного рівня дослідження: абстрагування, аналогію, аналіз, узагальнення, що спрямовані на виявлення проблем і суперечностей, пов'язаних із хореографічною підготовленістю спортсменок у спортивній аеробіці.

Виклад основного матеріалу дослідження. Спортивна аеробіка характеризується художніми та етичними ознаками в спортивній діяльності 3 базовими кроками та їх модифікацією в невід'ємному поєднанні з елементами складності в залежності від прояву фізичних якостей та біомеханічної структури руху тощо. Сутність проблеми зводиться до того, що під час оцінювання спортсменів у цьому виді спорту враховують технічну підготовленість та артистизм виконання загальної композиції. 3 урахуванням цих факторів особливого значення у світлі нових завдань набуває розроблення ефективних шляхів удосконалення хореографічної підготовленості, що й необхідно постійно знаходити тренерам.

В останні роки робилися таки спроби. Однією 3 них було використання світлової платформи вдосконалення технічної майстерності в спортивній аеробіці та фітнесі під час навчально-тре- нувального процесу, за допомогою якої можна впевнено й без помилок відпрацьовувати певні хореографічні елементи, домогтися практично повної реалізації рухових можливостей спортсмена [3]. Власне, у зв'язку з унікальністю такої ситуації всього декілька повторень рекордного режиму досить для того, щоб спортсмен закріпив у своїй свідомості й у самій системі рухів ритміко-швидкісну структуру змагального режиму [5]. Результати педагогічного експерименту показали доцільність використання розробленої і впровадженої в навчально-тренувальний процес світлової платформи для вдосконалення технічної майстерності в спортивній аеробіці. Отримані результати дослідження можуть використовуватися на етапі попередньої базової підготовки дітей 8-9-ти років у спортивній аеробіці, що дозволяє підвищити ступінь об'єднання всіх компонентів їхньої виконавчої майстерності [8;9].

Танцювальний рух $є$ формою візуального та кінестетичного мистецтва, що виходить за межі сенсорного поля, залучаючись до інтенсивного та особистісного типу спілкування. Як правило, намір руху може виходити як із внутрішньої сторони тіла, так і з його зовнішнього вигляду. Для творчого процесу цікавим $є$ те, що рух виникає зі сфери досить духовної, завдяки внутрішній натхненній силі.

Хореографічна композиція - це загальний та спеціальний аспекти спортивної аеробіки. Хореографічна підготовленість, як зазначає головний тренер збірної Запорізької області, Заслужений тренер України Світлана Атаманюк, відбувається шляхом механічного перенесення засад теорії та практики хореографічного мистецтва без урахування специфіки виду спорту [1], а базовим критерієм якісного формування виконання вправ у спортивній аеробіці $є$ культура рухів, а їх якість залежить від постійного вдосконалення.

Засвідчено про необхідність дбати про естетичне виховання, духовний та фізичний розвиток спортсменок, про правильну поставу, а все це здійснюється завдяки хореографічній підготовці. Серед суміжних акцентів виокремлюється постійне формування зацікавленості заняттями 3 аеробіки, на що рідше зважають тренери. Для вдосконалення цих навичок тренери вважають за доцільне відводити на заняття хореографією в середньому 40-45 хв. Щодо кратності занять на тиждень, то тренери одностайно рекомендують проводити повноцінне заняття хореографією хоча б раз на тиждень [8].

Дослідник Б. Кокарєв узагалі запропонував планувати композиційно-хореографічну підго- 
товку як окремий вид та розробив шкалу якісної оцінки рівня iï підготовленості висококваліфікованих спортсменок [2]. Науковці дотримуються точки зору, що для вдосконалення хореографічної підготовки необхідно посилити роботу над технікою виконання елементів у спортивній аеробіці, а також відпрацьовувати хореографічні рухи. Для цього бажано внести зміни в програмний матеріал iз хореографічної підготовки, адаптувати його відповідно до сучасних тенденцій розвитку спортивної аеробіки, а також до вікової специфіки спортсменок [7].

Хореографічна підготовка $\epsilon$ невід'ємним складником тренувального процесу спортсменів, a в іiі основі лежить класичний екзерсис, який разом 3 іншими засобами хореографії повинен відповідати правилам змагань, тенденціям розвитку і специфіці спортивної діяльності кожного окремого виду спорту [4]. Для вдосконалення спортивної аеробіки біля опори під час тренувань можна виконувати вправи класичної хореографії, зокрема, відпрацьовувати їх на середині залу, а також додавати елементи із сучасної хореографiї. Поступово тренерам бажано використовувати вправи із джаз-гімнастики, які дозволять покращувати рухливість і пластичність рук та плечового поясу. Для цього треба виконувати різноманітні вправи, де будуть задіяні прямі, колові та зігнуті положення рук. Можливість досягти більш високого розуміння та контролю над своїм тілом, отриманого завдяки хореографії, - це завдання, яке повинні виконувати тренери, щоб кожна кінцівка чи м'яз були яскраво представлені та могли виражати широкий спектр емоцій.

Румунські дослідники стверджують, що балет $\epsilon$ незамінною формою навчання гімнасток, тоді як танець модерн і постмодерн $є$ цінним джерелом натхнення для хореографів, зокрема, завдяки змішаним стилям, уявленням, культурам та жанрам танців [10]. Ученими розроблено структуровану модель для вивчення сучасного танцю, яка, вочевидь, підходить для подальшого розвитку, тому й хореографічна підготовка дотримується нових підходів і підкреслює нову, свіжу стилізацію рухів.

Удосконалювати рухи та положення ніг у спортивній аеробіці дозволяють елементи 3 дискогімнастики. Наприклад, це повторення махів прямими та зігнутими ногами в різні боки, а також із додаванням підскоків 3 положення стоячи та із зігнутих колін. Разом із тим за належного виконання попередніх вправ можна почати відпрацьовувати їх, підскакуючи на двох ногах, поступово згинаючи коліна.

Наступним етапом тренування спортивній аеробіці $є$ вдосконалення рухів тулуба. Це можливо здійснити завдяки елементам джаз-модерну або хіп-хопу, які характеризуються хвилеподібними рухами тулуба вперед і назад. Зіставлення засвідчує, що саме такі вправи дозволяють розвивати відчуття тіла в просторі, розвивають гнучкість поворотів, нахилів та удосконалюють загальновідому «вісімку» та спіраль тулуба. Окрім цього, краще відпрацьовуються положення ніг та тулуба в різних положеннях. Якщо необхідно покращити положення тіла на спині або боці, то можна трансформувати вправи зі стрейч-спрямуванням.

Завершальним етапом удосконалення хореографічної підготовленості спортсменок є положення тіла 3 елементами танцю на середині залу. Зокрема, додавання в спортивну аеробіку акробатичних етюдів, стійки на руках, лопатках, різні перекиди та виконання «мосту». Також необхідно зважати на музичний супровід, аби він гармонійно вплітався в загальну концепцію тренування та створював ритмічну виставу.

Оскільки хореографічна підготовка поліфункціональна, бо вона характеризується якісним виконанням хореографічних елементів, необхідно звертати увагу на вдосконалення музичних та артистичних компонентів у процесі тренування, виконувати танцювальні елементи в нестандартних умовах та одночасно здійснювати корекцію недоліків фізичної підготовленості, використовуючи хореографічні засоби, що дозволить покращити стійкість тіла та виконання техніки адажіо та алегро. Тренери повинні глибше розуміти танець як фундаментальну форму людського самовираження, яку в різних формулах може бути перенесено на спортивну арену [11]. Можна сказати, що хореографічна підготовка кидає виклик гравітації або використовує ï, врівноважує енергію та міць, створює ідеальні лінії та обсяги, що поєднують музику, причому всі ці елементи безперечно важливі.

Наприклад, дослідниками вказано на об'єднання танцювальних рухів із нескладними елементами акробатики, малої акробатики, різноманітними стрибками, рівновагами, нахилами, партерними рухами, елементами сучасного танцю. Такими можуть бути хореографічна розминка на середині залу, комбінація стрибків, поворотів і виразних поз, виконаних під сучасну музику, або спеціальні етюди на задану тему. Заняття з хореографії на цьому етапі мають стати більш насиченими та різноплановими [6]. Також слід звернути увагу на вдосконалення техніки виконання хореографічних стрибків, загальної координації, пластичних рухів; комбінацій різних елементів танців.

Фахівцями під час тренування пропонується для вдосконалення використовувати сучасні стилі: модерн, джаз, хіп-хоп, реп, рок-н-рол, брейк. Також об'єднувати елементи акробатики 3 елементами хореографії біля опори, гімнастичної 
стінки або на середині: статичні (рівноваги, шпагати, упори, стійкі) і динамічні (перекати, перекиди, перекидання, колеса, курбети, напівперевороти, перевороти, сальто) вправи, що включають елементи індивідуальної роботи. Для розвитку навичок злитого виконання декількох елементів рекомендують поєднувати вивчені елементами 3 новими [6].

Підсумовуючи, для закріплення результатів удосконалення хореографічної підготовленості необхідно повторювати вправи, зважати на індивідуальну манеру виконання рухів та комбінацій. Це можна здійснювати в усній комунікації, зокрема, проводити бесіди, презентувати аналіз похибок, розповідати про подальші дії. Закріплювати результати потрібно, здійснюючи самоконтроль, заміняти умови та способи виконання, також наполягати на імпровізованому виконанні комбінацій. Удосконалення може бути довготривалим, адже воно пов'язано з освітніми знаннями та навичками спортсменок, які впливатимуть на якість виконання різних елементів. Тому необхідно застосовувати комплексний підхід для одночасного покращення танцювальних та фізичних якостей, синтезувати різні засоби та методи, дбати про всебічний розвиток спортсменок.

Висновки. Здійснений аналіз дає змогу дійти висновку, що хореографічна підготовка $є$ важливою складовою частиною тренування в спортивній аеробіці як із практичної, так і з методичної точки зору. Також це питання $є$ актуальним для науковців, адже потребує постійних пошуків шляхів оптимізації. Спортивна аеробіка належить до популярних видів спорту, тому методику тренування має бути адаптовано до індивідуальних особливостей спортсменок і сучасних викликів хореографічної майстерності. Постає необхідність у створенні інноваційних технічних альтернатив програмам як у художній, так і в спортивній аеробіці. У цьому контексті необхідно звернути увагу на систему оцінювання, методичне забезпечення результатів тренувань і спортивних досягнень, засоби та інформаційні технології комплексного оцінювання в спортивній аеробіці, які сприятимуть підвищенню змагального результату. Потребує вдосконалення й нормативно-документарна база, програмне забезпечення, система контролю та змагальні програми хореографічної підготовленості в спортивній аеробіці.

\section{ЛIТЕРАТУРА}

1. Атаманюк С.І. Особливості тренувального процесу в аеробній гімнастиці в рамках загальної теорії тренування координаційних здібностей. Теорія і практика фізичного виховання. 2012. № 2. С. 86-93.

2. Кокарев Б.В. Побудова тренувального процесу висококваліфікованих спортсменок у спортивній аеробіці в річному циклі підготовки : дис ... канд. наук з фіз. виховання і спорту : 24.00.01 «Олімпійський і професійний спорт» ; Дніпропетр. держ. ін-т фіз. культури і спорту. Дніпропетровськ, 2015. $224 \mathrm{c}$.

3. Світлова платформа вдосконалення технічної майстерності у спортивній аеробіці та фітнесі (СПВТМСАФ) : Пат. 94894 Україна, МПК (2014.01) А63В 23/04 / В.О. Тищенко, Б.В. Кокарев № u201404788 ; заявл. 05.05.2014 ; опубл. 10.12.2014, Бюл. № 23.

4. Сосіна В.Ю. Особливості хореографічної підготовки в спорті. Dance studies. 2020. Vol. 3. № 1. P. 72-79.

5. Тищенко В. Світлова платформа для вдосконалення технічної майстерності у спортивній аеробіці та фітнес. Фізична активність, здоров’я і спорт. 2017. № 4 (30). С. 50-55.

6. Тодорова В., Долинський Б., Пасічна Т. Удосконалення змісту хореографічної освіти в аеробіці на етапі спеціалізованої базової підготовки спортсменів. Science and Education. 2020. Issue 1. P. 60-65.

7. Тодорова В., Сосіна В., Погорелова О. Удосконалення програми хореографічної підготовки в спортивній аеробіці на етапі початкової підготовки. Фізична активність, physical activity. Здоров'я $i$ cnopm. 2018. № 2 (32). С. 44-50.

8. Удосконалення змісту хореографічної підготовки в спортивній аеробіці на етапі попередньої базової підготовки / В. Тодорова та ін. Спортивна наука Украӥни. 2019. № 1 (89). С. 93-99.

9. Шеховцова К.В., Тищенко В.О. Застосування інноваційних технічних засобів для вдосконалення спеціальної технічної підготовленості спортсменок у спортивній аеробіці. Перспективи, проблеми та наявні здобутки розвитку фізичної культури і спорту в Україні : матеріали IV Всеукраїнської електронної конференції «COLOR OF SCIENCE», (Вінниця, 29 січня 2021 р.) / ред. А.А. Дяченко ; Вінницький державний педагогічний університет імені Михайла Коцюбинського. Вінниця, 2021. C. 264-266.

10. Bota A., Lautarua C. Contemporary Trends in Choreography-Potential for Enhancing the Artistic Preparation in Rhythmic and Aerobic Gymnastics. The European Proceedings of Social \& Behavioural Sciences. 2016. C. 22-29.

11. Cerny Minton S. Choreography. A Basic Approach Using Improvisation. Human Kinetics. 2007. C. $78-84$. 


\section{REFERENCES}

1. Atamanyuk S. I. (2012) Osoblyvosti trenuval'noho protsesu v aerobniy himnastytsi v ramkakh zahal'noyi teoriyi trenuvannya koordynatsiynykh zdibnostey [Features of the training process in aerobic gymnastics in the general theory of training coordination skills]. Teoriya i praktyka fizychnoho vykhovannya. № 2. S. 86-93.

2. Kokarev B.V. (2015) Pobudova trenuval'noho protsesu vysokokvalifikovanykh sport-smenok u sportyvniy aerobitsi v richnomu tsykli pidhotovky [Construction of the training process of highly qualified athletes in sports aerobics in the annual cycle of training]: dys ... kand. nauk z fiz. vykhovannya i sportu; Dnipropetr. derzh.in-t fiz. kul'tury i sportu. Dnipropetrovs'k.

3. Svitlova platforma vdoskonalennya tekhnichnoyi maysternosti u sportyvniy aerobitsi ta fitnesi (SPVTM$S A F)$ [Light platform for improving technical skills in sports aerobics and fitness (SPVTMSAF)]: Pat. 94894 Ukrayina, MPK (2014.01) A63V 23/04 / Tyshchenko V. O., Kokarev B. V. № u201404788; zayavl. 05.05.2014; opubl. 10.12.2014, Byul. № 23.

4. Sosina V. YU. (2020) Osoblyvosti khoreohrafichnoyi pidhotovky v sporti [Features of choreographic training in sports]. Dance studies. Vol. 3. № 1. P. 72-79.

5. Tyshchenko V. (2017) Svitlova platforma dlya vdoskonalennya tekhnichnoyi maysternosti u sportyvniy aerobitsi ta fitnes [Light platform for improving technical skills in sports aerobics and fitness]. Physical activity, health and sports. № 4 (30). S. 50-55.

6. Todorova V., Dolyns'kyy B., Pasichna T. (2020) Udoskonalennya zmistu khoreohrafichnoyi osvity v aerobitsi na etapi spetsializovanoyi bazovoyi pidhotovky sport-smeniv [Improving the content of choreographic education in aerobics at the stage of specialized basic training of athletes]. Science and Education. Issue 1. R. 60-65.

7. Todorova V., Sosina V., Pohorelova O. (2018) Udoskonalennya prohramy khoreohrafichnoyi pidhotovky v sportyvniy aerobitsi na etapi pochatkovoyi pidhotovky [Improving the program of choreographic training in sports aerobics at the stage of initial training]. Physical activity, health and sports. Zdorov'ya i sport. № 2(32). C. 44-50.

8. Todorova V., Fidirko M., Pasichna T., Podhorna V. (2019) Udoskonalennya zmistu khoreohrafichnoyi pidhotovky v sportyvniy aerobitsi na etapi poperedn'oyi bazovoyi pidhotovky [Improving the content of choreographic training in sports aerobics at the stage of preliminary basic training]. Sports science of Ukraine. № 1(89). S. 93-99.

9. Shekhovtsova K. V., Tyshchenko V. O. (2021) Zastosuvannya innovatsiynykh tekhnichnykh zasobiv dlya vdoskonalennya spetsial'noyi tekhnichnoyi pidhotovlenosti sport-smenok u sportyvniy aerobitsi [The use of innovative technical means to improve the special technical training of athletes in sports aerobics]. Perspektyvy, problemy ta nayavni zdobutky rozvytku fizychnoyi kul'tury i sportu v Ukrayini : materialy IV Vseukrayins'koyi elektronnoyi konferentsiyi «COLOR OF SCIENCE», (Vinnytsya, 29 sichnya 2021 r.) / red. A. A. Dyachenko; Vinnyts'kyy derzhavnyy pedahohichnyy universytet imeni Mykhayla Kotsyubyns'koho. Vinnytsya. S. 264-266.

10. Bota A., Lautarua C. (2016) Contemporary Trends in Choreography-Potential for Enhancing the Artistic Preparation in Rhythmic and Aerobic Gymnastics.The European Proceedings of Social \& Behavioural Sciences. C. 22-29.

11. Cerny Minton S. (2007) Choreography. A Basic Approach Using Improvisation. Human Kinetics. C. 78-84. 